\title{
Effects of Human Activities on the Spatial Distribution, Ecological Risk and Sources of PTEs in Coastal Sediments
}

\author{
Weili Wang ${ }^{1, *}$, Cai Lin ${ }^{1}$, Lingqing Wang ${ }^{2}{ }^{\oplus}$, Ronggen Jiang ${ }^{1}$, Yang Liu ${ }^{1}$, Hui Lin ${ }^{1}$ and Jinmin Chen ${ }^{1}$ \\ 1 Third Institute of Oceanography, Ministry of Natural Resources, Xiamen 361005, China; \\ lincai@tio.org.cn (C.L.); jiangronggen@tio.org.cn (R.J.); jczx_liuyang@tio.org.cn (Y.L.); linhui@tio.org.cn (H.L.); \\ chenjinmin@tio.org.cn (J.C.) \\ 2 Institute of Geographical Sciences and Natural Resources Research, Chinese Academy of Sciences, \\ Beijing 100101, China; wanglq@igsnrr.ac.cn \\ * Correspondence: wangweiliad@tio.org.cn
}

check for updates

Citation: Wang, W.; Lin, C.; Wang, L.; Jiang, R.; Liu, Y.; Lin, H.; Chen, J. Effects of Human Activities on the Spatial Distribution, Ecological Risk and Sources of PTEs in Coastal Sediments. Int. J. Environ. Res. Public Health 2021, 18, 12476. https:// doi.org/10.3390/ijerph182312476

Academic Editors: Marta Otero and Giulia Maisto

Received: 24 September 2021 Accepted: 24 November 2021 Published: 26 November 2021

Publisher's Note: MDPI stays neutral with regard to jurisdictional claims in published maps and institutional affiliations.

Copyright: (c) 2021 by the authors. Licensee MDPI, Basel, Switzerland. This article is an open access article distributed under the terms and conditions of the Creative Commons Attribution (CC BY) license (https:// creativecommons.org/licenses/by/ $4.0 /)$.
Abstract: Potentially toxic elements (PTEs) have attracted substantial attention because of their widespread sources, long residue time and easy accumulation. PTEs in the surface sediments of inshore waters are strongly affected by human activities because these waters are a zone of interaction between the ocean and land. In the present study, to explore the environmental geochemical behaviour and source of PTEs in the surface sediments of coastal waters, the contents and spatial distributions of copper $(\mathrm{Cu})$, lead $(\mathrm{Pb})$, zinc $(\mathrm{Zn})$, cadmium $(\mathrm{Cd})$, chromium $(\mathrm{Cr})$, mercury $(\mathrm{Hg})$ and arsenic (As) in different regions of Xiamen Bay were investigated. The data were processed by multivariate statistical methods, and the distribution characteristics of PTEs in the surface sediments of Xiamen Bay were analysed. In addition, the pollution load index (PLI), geo-accumulation index (Igeo) and potential ecological index(RI) were used to evaluate the pollution degree and potential risk in the surface sediments of Xiamen Bay, and the positive matrix factorisation (PMF) model was used to analyse the source. The results show that $\mathrm{Zn}$ had the highest mean concentration, followed by $\mathrm{Pb}$, $\mathrm{Cr}, \mathrm{Cu}$, As, $\mathrm{Cd}$ and $\mathrm{Hg}$, among the seven PTEs. The mean contents of $\mathrm{Pb}, \mathrm{Zn}, \mathrm{Cd}, \mathrm{Cu}$ and $\mathrm{Hg}$, and especially $\mathrm{Hg}$ and $\mathrm{Cd}$, were higher than the corresponding environmental background values. The average PLI value indicated that the Xiamen Bay sediment was moderately contaminated by PTEs. The Igeo results showed that Xiamen Bay was moderately to strongly polluted by $\mathrm{Cd}$ and $\mathrm{Hg}$. The proportions of samples with low, medium and strong risk levels were $11.63 \%, 74.42 \%$, and $13.95 \%$ in surface sediments, respectively. PMF models showed that the input of chemical fertilizer and medication, anthropogenic atmospheric components and terrestrial detritus were the main sources of PTEs in the surface sediment of Xiamen Bay.

Keywords: potentially toxic elements; Xiamen Bay; sediment; PMF model; risk assessment

\section{Introduction}

As an important part of the marine ecosystem, sediment is the main enrichment medium for terrestrial pollutants after they enter the sea and an important habitat for aquatic organisms [1]. Due to its higher stability than that of water medium, sediment can more accurately indicate the quality status and trend of the marine environment [2-4]. Potentially toxic elements (PTEs) are important pollutants of concern in the marine environment and mainly originate from surface runoff, atmospheric deposition and direct offshore pollution [5-8]. They can be deposited in sediments through the adsorption of suspended particulates $[5,9,10]$. Due to the characteristics of accumulation and long residue time, PTEs easily accumulate in benthic organisms and transfer to predators or human bodies through the food chain [11], thereby endangering aquatic organisms and human health [7,12-14]. When the conditions external to the sediment (such as $\mathrm{pH}$ and redox conditions) change, the accumulated PTEs in the sediment may be released into the water again [15]. Therefore, PTEs in sediments not only have a direct toxic effect on benthic 
organisms but also pose potential threats to the ecosystem through secondary release, bioaccumulation, and amplification [16].

Previous studies have found that the concentration and distribution of PTEs in marine sediments are mainly affected by particle size, natural sources and human activities [17-19]. Most of the PTEs were transported to the ocean in the form of weathered debris. In addition, wastewater containing PTEs closely related to human activities had also been discharged into the sea, and all these PTEs entering the sea accumulated in sediments, resulting in PTEs pollution [20-22].

Xiamen Bay, which is located in the western Taiwan Strait of China, is an important sea outlet along the southeastern coast of China. There are many islands and reefs in the sea area, with vertical and horizontal ditches and branches, and they are filled by the Jiulong River and Xi River. The sedimentary pattern, environment and process of sediments in Xiamen Bay are significantly affected by terrestrial sources. There are many types of sediments in Xiamen Bay, mainly clayey silt [23]. The clay minerals in the sediments are mainly illite, kaolinite, chlorite and montmorillonite, and Jiulong River runoff transport is the main factor for the formation of clay mineral deposits in Xiamen Bay. The rapid development of the regional economy has also brought much pollution to coastal waters [24,25]. In the present study, the contents of PTEs in the surface sediments of Xiamen Bay (Jiulong River Estuary, Xiamen West Harbour, Tongan Bay, Eastern Channel and Southern Channel) were investigated, and our aims were to (1) analyse the spatial differences and factors influencing the distribution of PTEs in sediments; (2) evaluate the pollution degree and potential biological hazards of PTEs; and (3) explore the main source of PTE pollution in surface sediments, which helps to correctly delineate the functions of different sea areas, reasonably protect the ocean and ensure the sustainable development of the marine economy in Xiamen Bay.

\section{Materials and Methods}

\subsection{Study Area}

Xiamen Bay is a semi-closed compound estuarine bay in southern Fujian Province, China [26]. The water area is $154.18 \mathrm{~km}^{2}$, with a depth of $10 \mathrm{~m}$ extending along the centre of the outer and inner harbours, and the maximum water depth is $31 \mathrm{~m}$. The Jiulong River, the largest river in Xiamen Bay, has an annual maximum runoff of $288 \times 10^{8} \mathrm{~m}^{3}[27,28]$. Xiamen Bay is located in the economically developed coastal area of China, which have frequent human activities $[29,30]$. In order to better study the content and distribution characteristics of PTEs in Xiamen Bay sediments, according to the ecological environment, industrial layout and surrounding administrative divisions, the study area was divided into 6 sub-regions: Jiulong River Estuary (sites 01 04), Southern Waters (sites 05 08), Western Waters (sites 09 16), Tongan Bay (sites 17 29), Eastern Waters (sites 30 35) and Dadeng Waters (sites 36 43) (Figure 1).

\subsection{Sampling and Analysis}

A total of 43 surficial sediment samples were collected at depths approximately between 0 and $5 \mathrm{~cm}$ with a grab-type dredger. We used the hydrological winch to settle the clam mud collector to the selected sampling point for sampling. When sampling, we opened the upper cover of the mud collector and gently tilt the mud collector to make the upper water flow out slowly. According to the specification for marine monitoring (GB17378.3-2007), in order to make the sediment samples representative, we sampled 2-3 times around the same sampling point and mixed the collected samples evenly. These samples were collected with clam grab and the undisturbed part of the surface layer was placed in a polyethylene sealed bag that was soaked in a dilute nitric acid solution, dried, refrigerated, and brought back to the laboratory in 8 to 10 May 2017 (Figure 1).

After air drying, the samples were ground and sieved for further pretreatment.

PTEs in the sediments were tested and analysed by different methods. Among them, $\mathrm{Cu}, \mathrm{Zn}, \mathrm{Cr}, \mathrm{Cd}, \mathrm{As}$ and $\mathrm{Pb}$ were digested $(0.5 \mathrm{~g})$ by the $\mathrm{HNO}_{3}-\mathrm{HF}-\mathrm{HClO}_{4}$ system and 
detected by a 7700X ICP-MS produced by Agilent (Santa Clara, CA, USA). The level of $\mathrm{Hg}$ was detected by an AFS-930 atomic fluorescence spectrometer by Titan Instruments (Beijing, China).

The content of sulfide in sediments was determined by methylene blue spectrophotometry, and the concentration of total organic carbon (TOC) in sediments was determined by the potassium dichromate redox volumetric method.

All samples to be processed were measured in parallel at $10 \%$ of the total amount to check possible errors during sample processing. A blank sample test was used to eliminate systematic errors. The internal standard method was used to test and compensate for the fluctuation in the analytical signal to improve the precision and accuracy of determination. The recovery rate of the standard addition was tested by adding the same sample to every 10-20 samples. The recovery rate of the reference materials was $85 \sim 115 \%$, meeting the quantification limits (80-115\%).

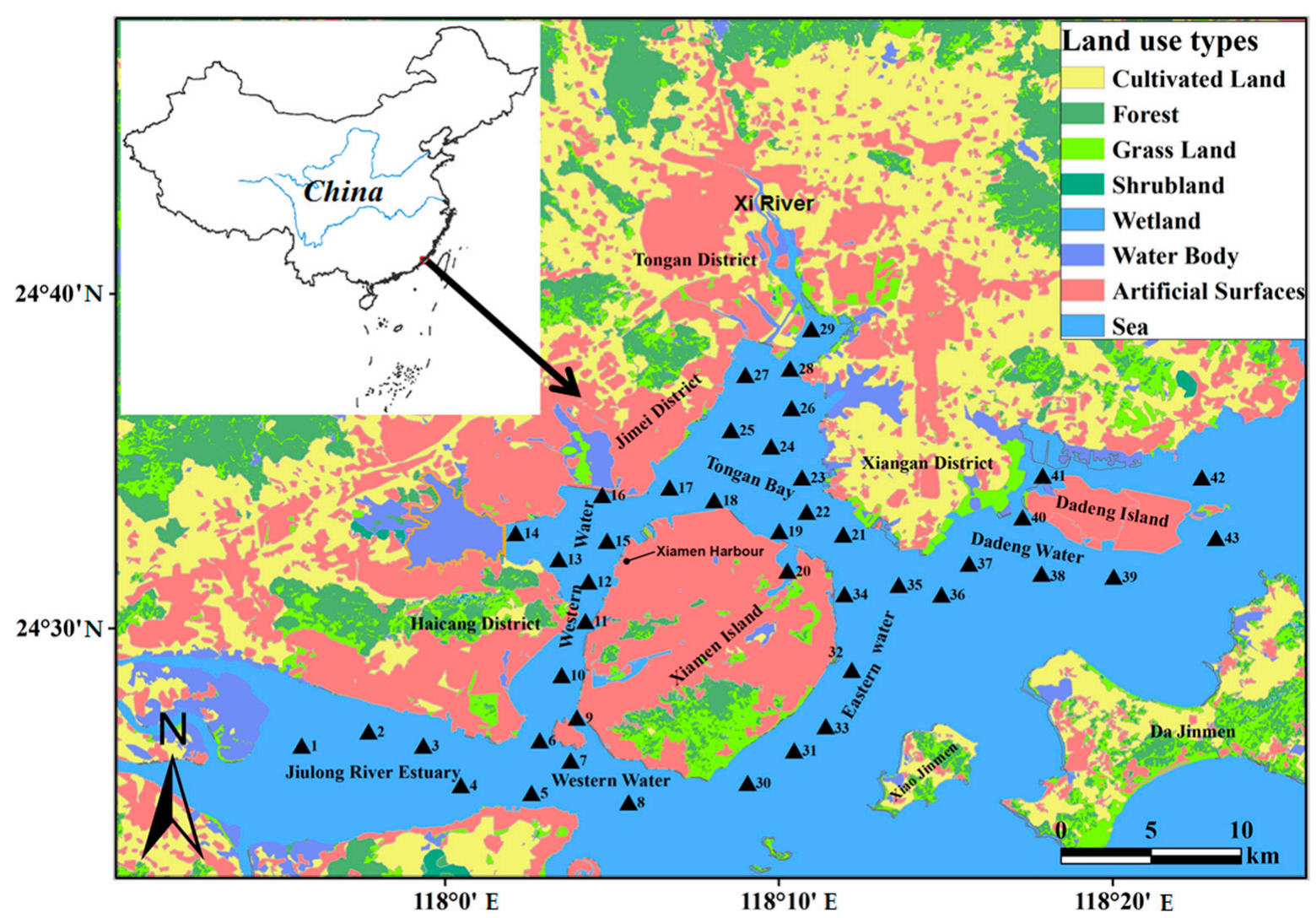

Figure 1. Sampling sites for surface sediments in Xiamen Bay ( $\mathbf{\Delta}$ : Sediment Sampling; 1-43: Station numbers).

\subsection{Data Processing}

To analyse the source characteristics of PTEs and determine the characteristics affecting the content and geochemical distribution of PTEs in sediments, Pearson correlation analysis was carried out for 7 kinds of PTEs in sediments and their geochemical parameters, such as TOC. SPSS 20.0 was used for data processing and correlation analysis. The spatial distribution of PTEs was made by inverse distance interpolation through ArcGIS 10.3. In the above statistical analysis, the significant difference level was expressed as $p<0.05$.

\subsection{Sediment Contamination and Risk Assessment Methods}

\subsubsection{Pollution Load Index (PLI)}

The pollution load index (PLI) is widely used to determine the pollution status of all PTEs in studies [16,31-33]. Before using the pollution load index (PLI) for evaluation, the contamination factors ( $\mathrm{CFs}$ ) of each metal element need to be calculated. As a simple 
and rapid method, $\mathrm{CFs}$ have been widely used to calculate the pollution degree of a single metal element [34-36]. The CFs and PLI of PTEs in surface sediments were calculated using Equations (1) and (2), respectively:

$$
\begin{gathered}
C F=\frac{C_{i}}{C_{n}} \\
\text { PLI }=\sqrt[n]{C_{1} \times C F_{2} \cdots F_{n}}
\end{gathered}
$$

where $C_{i}$ represents the monitored concentration of the element metal $i$ and $C_{n}$ represents the corresponding sediment background value (Table 1. Background Value). According to previous studies, the CF can be classified into four contamination levels [36,37]: low pollution $(<1)$; moderate pollution (1 3); considerable pollution (3 6); and very high pollution $(\geq 6)$. The PLI can be classified into two cases according to the PLI value of total PTEs: no contamination (PLI $\leq 1)$ and contamination (PLI > 1) [15].

\subsubsection{Geo-Accumulation Index (Igeo)}

The geo-accumulation index (Igeo), which was first proposed by Muller [37], is a quantitative index to study PTEs pollution in sediments. It is widely used to study the contamination of PTEs pollution in modern sediments [38-40]. To characterise the level of contamination within the sediment, Igeo values were measured using the formula given below:

$$
\mathrm{I}_{\text {geo }}=\log _{2}\left(\mathrm{C}_{\mathrm{x}} / 1.5 \mathrm{~B}_{\mathrm{x}}\right)
$$

where $C_{x}$ is the measured concentration of metal element $x$ in the samples; $B_{x}$ is the reference or background value of element $x$ (Table 1. Background Value).

According to the Igeo value, the pollution degree of PTEs in sediments can be divided into 7 levels [41,42]:

$$
\text { Igeo }=\left\{\begin{array}{ccc}
<0 & \text { no pollution } \\
0 & \sim 1 \quad \text { no to moderate pollution } \\
1 & \sim 2 \quad \text { moderate pollution } \\
2 & \sim 3 \text { moderate to strong pollution } \\
3 & \sim 4 \quad \text { strong pollution } \\
4 & \sim 5 \text { strong to extreme pollution } \\
& >5 & \text { extreme pollution }
\end{array}\right.
$$

\subsubsection{Ecological Risk Assessment}

In this study, the potential ecological index (RI) from Swedish scientist Hakanson [43] was cited to assess the ecological risk in the surface sediments of Xiamen Bay. This method obtains the pollution coefficient of PTEs through the single factor index method, combined with the toxicity coefficient of different metal elements, to evaluate the degree of harm of PTEs quickly and easily to the ecological environment $[44,45]$. The RI was calculated using Equations (5) and (6) [6]:

$$
\begin{gathered}
\mathrm{E}_{\mathrm{r}}^{\mathrm{i}}=\mathrm{T}_{\mathrm{r}}^{\mathrm{i}} \times \frac{\mathrm{C}^{\mathrm{i}}}{\mathrm{C}_{\mathrm{n}}^{\mathrm{i}}} \\
\mathrm{RI}=\sum_{\mathrm{i}=1}^{\mathrm{m}} \mathrm{E}_{\mathrm{r}}^{\mathrm{i}}
\end{gathered}
$$

where $C^{i}$ is the content of metal $i$ in the sediment; $C_{n}^{i}$ is the background content of metal $i$ in the sediment (Table 1. Background Value); $\mathrm{E}_{\mathrm{r}}^{\mathrm{i}}$ is the potential ecological risk coefficient of element $\mathrm{i}$; and $\mathrm{T}^{\mathrm{i}}$ is the toxicity response factor of each element $\left(\mathrm{T}^{\mathrm{Cu}}{ }_{\mathrm{r}}=5 ; \mathrm{T}^{\mathrm{Pb}}{ }_{\mathrm{r}}=5\right.$; $\left.\mathrm{T}^{\mathrm{Cd}}{ }_{\mathrm{r}}=30 ; \mathrm{T}_{\mathrm{r}}^{\mathrm{Zn}}=1 ; \mathrm{T}_{\mathrm{r}}^{\mathrm{Cr}}=40 ; \mathrm{T}_{\mathrm{r}}^{\mathrm{As}}=1 ; \mathrm{T}^{\mathrm{Hg}}{ }_{\mathrm{r}}=10\right)$. 
The categories for $\mathrm{E}_{\mathrm{r}}^{\mathrm{i}}$ and RI were as follows in Equations (7) and (8), respectively.

$$
\begin{gathered}
\mathrm{E}_{\mathrm{r}}^{\mathrm{i}}=\left\{\begin{array}{cc}
<40 & \text { Low risk degree } \\
40-80 & \text { Moderate risk degree } \\
80-160 & \text { Considerable risk degree } \\
160-320 & \text { Very high risk degree } \\
>320 & \text { Disastrous risk degree }
\end{array}\right. \\
\mathrm{RI}=\left\{\begin{array}{cc}
<150 & \text { Low risk degree } \\
150-300 & \text { Moderate risk degree } \\
300-600 & \text { Considerable risk degree } \\
>600 & \text { High risk degree }
\end{array}\right.
\end{gathered}
$$

\subsubsection{Positive Matrix Factorisation (PMF)}

A positive matrix factorisation (PMF) model can not only optimize data through the standard deviation of the data but also deal with missing and inaccurate data to ensure data reliability $[40,46]$. This method is a quantitative method for the matrix analysis of pollution sources based on the receptor model. It composes a matrix of collected samples and a variety of PTEs, which is decomposed into the contribution rate matrix of the pollution source and the pollution source component spectrum matrix through matrix operation, and then iterative operation is carried out through the least squares method to obtain the pollution source composition $[46,47]$.

\begin{tabular}{|c|c|c|c|c|c|c|c|c|}
\hline PTEs (mg/kg) & $\mathrm{Cu}$ & $\mathrm{Pb}$ & $\mathrm{Zn}$ & $\mathrm{Cd}$ & $\mathrm{Cr}$ & $\mathrm{Hg}$ & As & References \\
\hline Min & 0.4 & 12.3 & 16.3 & 0.032 & 1.5 & 0.006 & 1.9 & \\
\hline Max & 69.6 & 68.2 & 188.0 & 0.419 & 70.0 & 0.160 & 13.1 & \\
\hline Average & $18.8 \pm 13.7$ & $41.4 \pm 14.8$ & $82.5 \pm 32.6$ & $0.135 \pm 0.084$ & $20.6 \pm 15.1$ & $0.079 \pm 0.033$ & $7.0 \pm 2.6$ & \\
\hline $\begin{array}{l}\text { Coefficient of } \\
\text { Variation }\end{array}$ & $73.1 \%$ & $35.7 \%$ & $39.5 \%$ & $62.6 \%$ & $73.3 \%$ & $41.7 \%$ & $36.7 \%$ & \\
\hline Kurtosis & -1.14 & 5.21 & 4.39 & -0.85 & 1.41 & 3.64 & 2.76 & \\
\hline Skewness & 0.15 & 2.08 & 1.94 & -0.14 & 0.66 & 1.76 & 1.67 & \\
\hline Bohai Bay, China & $32.6 \pm 7.0$ & $26.9 \pm 3.4$ & $95.2 \pm 19.7$ & $0.300 \pm 0.1$ & $75.2 \pm 13.1$ & $0.072 \pm 0.042$ & $12.9 \pm 3.1$ & [48] \\
\hline $\begin{array}{l}\text { Hangzhou Bay, } \\
\text { China }\end{array}$ & $27.2 \pm 6.0$ & $21.2 \pm 17.3$ & $86.0 \pm 17.3$ & $0.214 \pm 0.070$ & $61.7 \pm 10.3$ & $0.050 \pm 0.011$ & $9.4 \pm 5.0$ & [49] \\
\hline Daya Bay, China & $16.5 \pm 6.3$ & $37.0 \pm 8.5$ & $87.8 \pm 26.4$ & $0.07 \pm 0.02$ & $59.0 \pm 16.6$ & $0.04 \pm 0.01$ & $8.16 \pm 1.99$ & [50] \\
\hline $\begin{array}{c}\text { Thessaloniki Bay, } \\
\text { Greece }\end{array}$ & $77.2 \pm 46.5$ & $84.2 \pm 53.8$ & $218 \pm 157.9$ & $2.51 \pm 3.57$ & $115.4 \pm 34$ & - & - & [51] \\
\hline Class I, China & 35.0 & 60.0 & 150.0 & 0.50 & 80.0 & 0.20 & 20.0 & [52] \\
\hline Class II, China & 100.0 & 130.0 & 350.0 & 1.50 & 150.0 & 0.50 & 65.0 & [52] \\
\hline $\begin{array}{l}\text { Background } \\
\text { Value }\end{array}$ & 15.0 & 20.0 & 65.0 & 0.065 & 60.0 & 0.025 & 7.7 & [53] \\
\hline
\end{tabular}

Table 1. Descriptive statistics for PTEs in surface sediment in Xiamen Bay and other areas.

\section{Results and Discussion}

\subsection{Geochemistry and Distribution of PTES}

Table S1 shows the concentrations of PTEs in each sampling station in Xiamen Bay and the Table 1 shows the descriptive statistical analysis and the background values of the PTEs contents in the surface sediments in Xiamen Bay. The average abundance data of elements in the earth's crust or the average shale value are often used as its environmental background value, while $\mathrm{Xu}$ et al. [52] believe that the regional background value may be more appropriate. In this study, the baseline/background metal concentrations in continental shelf sediments of China were used as the background metal values shown in Table 1 [53]. Among the seven PTEs in the investigated Xiamen Bay sediments, $\mathrm{Zn}$ had the highest mean content, followed by $\mathrm{Pb}, \mathrm{Cr}, \mathrm{Cu}, \mathrm{As}, \mathrm{Cd}$ and $\mathrm{Hg}$, with contents of $82.5 \pm 32.6 \mathrm{mg} / \mathrm{kg}, 41.4 \pm 14.8 \mathrm{mg} / \mathrm{kg}, 20.6 \pm 15.1 \mathrm{mg} / \mathrm{kg}, 18.8 \pm 13.7 \mathrm{mg} / \mathrm{kg}$, $7.0 \pm 2.6 \mathrm{mg} / \mathrm{kg}, 0.135 \pm 0.084 \mathrm{mg} / \mathrm{kg}$ and $0.079 \pm 0.033 \mathrm{mg} / \mathrm{kg}$, respectively. The coeffi- 
cients of variation of $\mathrm{Cu}, \mathrm{Cd}$ and $\mathrm{Cr}$ were higher than those of $\mathrm{Hg}, \mathrm{Zn}, \mathrm{Pb}$ and As, indicating that $\mathrm{Cu}, \mathrm{Cd}$ and $\mathrm{Cr}$ in sediments had a large spatial diversity.

According to Table 1, the average contents of copper, lead, zinc, cadmium and mercury were higher than the sediment background values, especially those of mercury and cadmium, which were more than two times the background values. Referring to the marine sediment quality in China (GB18668-2002) [52], the average contents of the seven PTEs in surficial sediments were lower than the limit of the class I sediment quality standard. The average contents of PTEs in Xiamen Bay were similar to those in other coastal regions in China and much lower than those in Thessaloniki Bay, Greece. A previous study found that the accumulation of PTEs in sediments was related to the frequency of economic activities [54].

The average contents of PTEs in surface sediment from Xiamen Bay are shown in Figure 2, and the spatial interpolation graph is presented in Figure 3. The average contents of copper and zinc in different areas were as follows: Western Waters $>$ Southern Waters $>$ Jiulong River Estuary > Tongan Bay $>$ Eastern Waters > Dadeng Waters; the mean concentrations of $\mathrm{Cr}$ were as follows: Southern Waters $>$ Western Waters $>$ Jiulong River Estuary > Tongan Bay > Eastern Waters > Dadeng Waters. The contents of $\mathrm{Cu}, \mathrm{Cr}$ and $\mathrm{Zn}$ had similar spatial distributions (Figure 3); the Southern Waters and Western Waters were the highest, and the Dadeng Waters were the lowest. The mean contents of lead, mercury and arsenic were higher in the Tongan Bay, Jiulong River Estuary and Western Waters and lower in the Dadeng Waters and Southern Waters. The average contents of Cd in surficial sediments were in descending order: Tongan Bay $>$ Jiulong River Estuary $>$ Western Waters $>$ Eastern Waters > Southern Waters > Dadeng Waters.
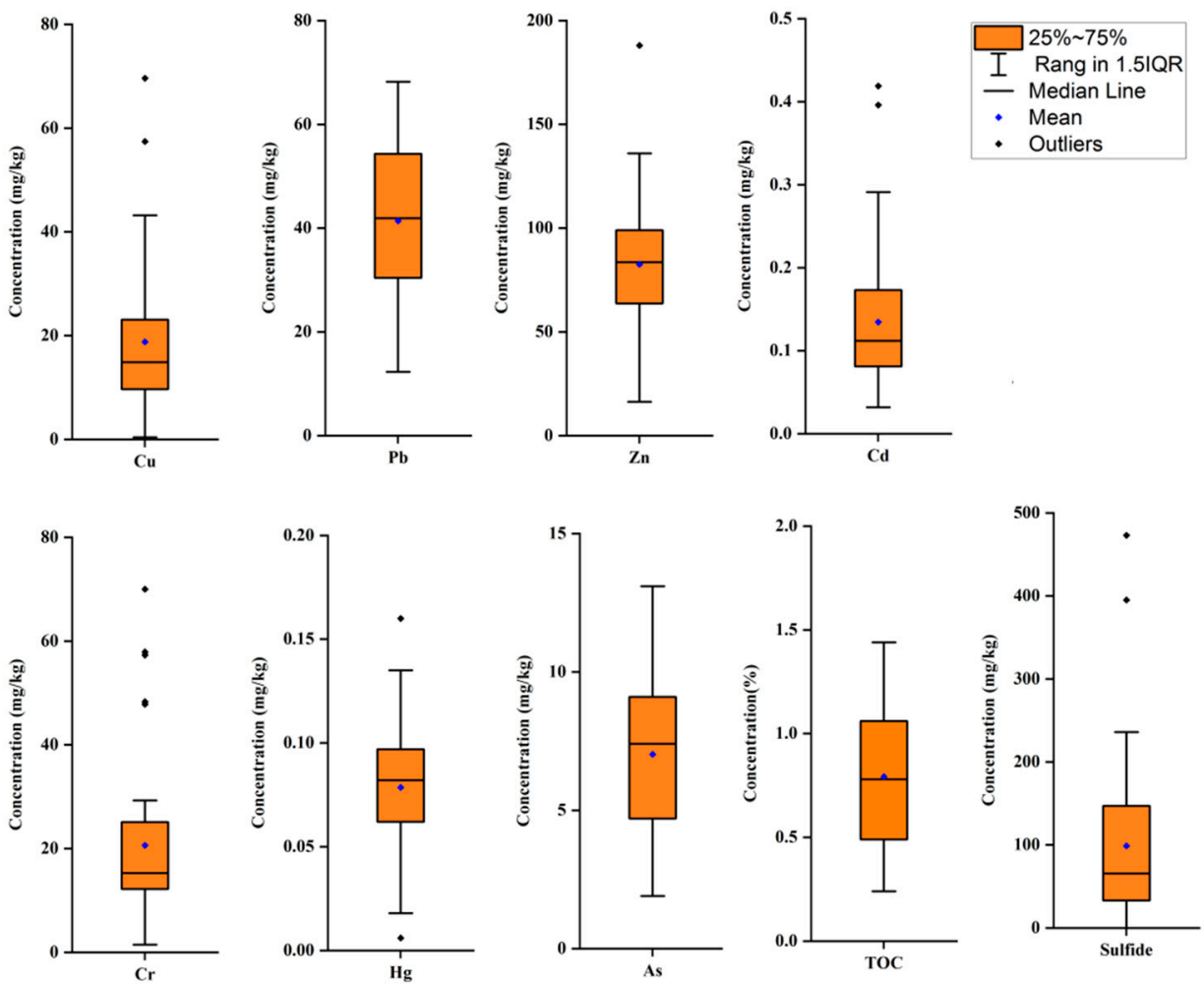

Figure 2. Box diagram showing the average contents of PTEs, TOC and Sulfide in Xiamen Bay.

The average concentrations of sulfide and TOC in the surface sediments were $98.8 \pm 98.5 \mathrm{mg} / \mathrm{kg}$ and $0.79 \pm 0.32 \%$, with coefficients of variation (CVs) of $99.7 \%$ and $40.3 \%$, respectively. The mean concentrations of sulfide and TOC were lower than the class I standard of marine sediment quality. 

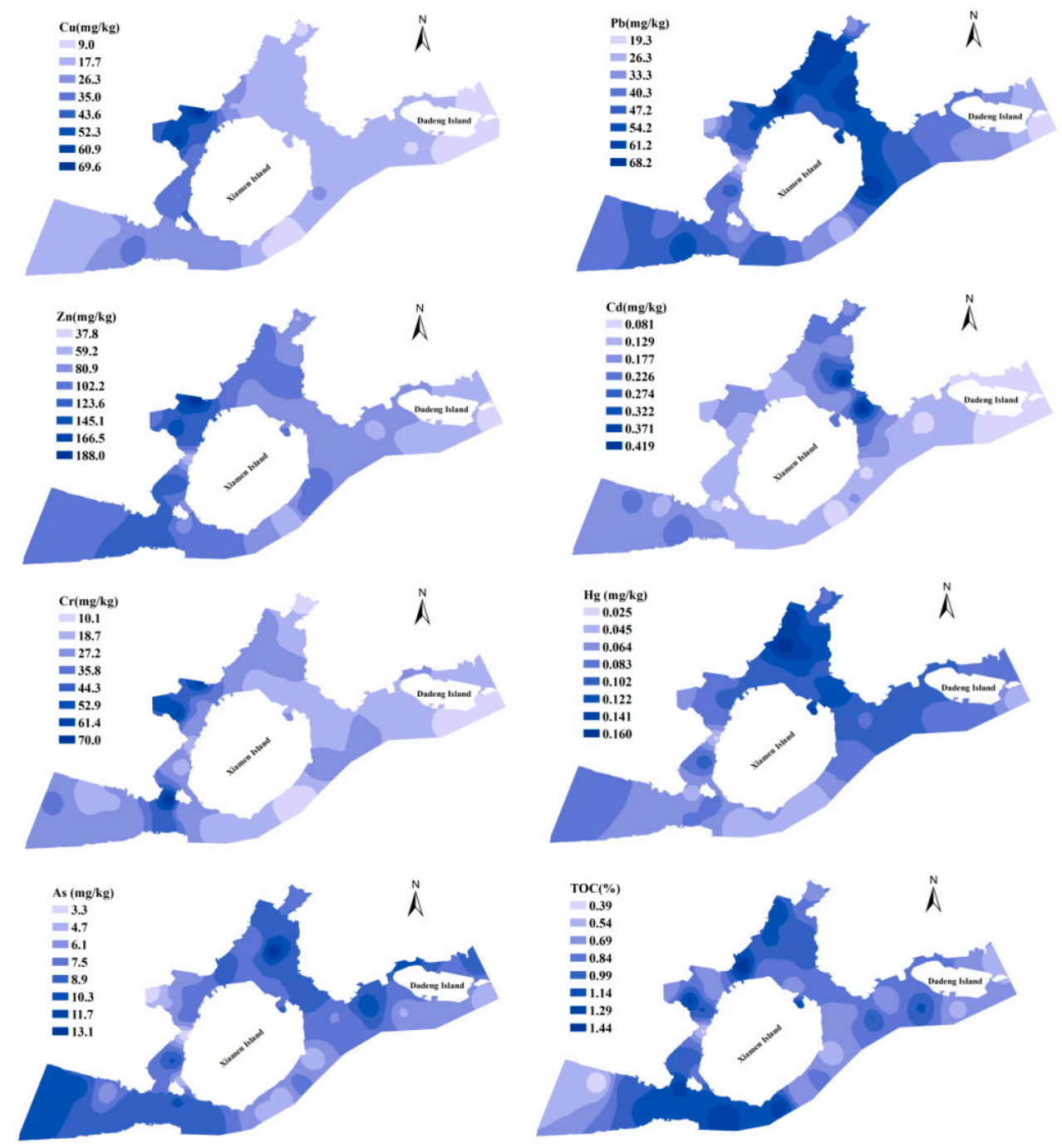

Figure 3. Spatial distribution of the PTEs contents (including $\mathrm{Cu}, \mathrm{Pb}, \mathrm{Zn}, \mathrm{Cd}, \mathrm{As}, \mathrm{Cr}$ and $\mathrm{Hg}$ ) and TOC in the surface sediments of Xiamen Bay.

\subsection{Pollution Index Evaluation}

\subsubsection{CFs and PLI}

The contamination factor $(\mathrm{CF})$ was deemed a useful method to evaluate the accumulation of PTEs in surface sediments over time [53]. The cluster heatmap of CFs from all sampling sites is presented in Figure 4. The CF ranges of copper, lead, zinc, cadmium, chromium, arsenic and mercury in the surface sediments of Xiamen Bay were 0.03 to 4.64, 0.62 to $3.41,0.25$ to $2.89,0.49$ to $6.45,2.07$ to $0.03,0.25$ to $1.70,0.24$ to 6.40 , and 0.19 to 1.96 , with average CFs of 1.25, 2.07, 1.27, 2.07, 0.34, 0.91, 3.14 and 1.21, respectively (Table 2, Figure 4). Among the different research areas, the Western Waters had the highest average $\mathrm{CFs}$ for $\mathrm{Cu}$ and $\mathrm{Zn}$, and Tongan Bay had the highest mean $\mathrm{CFs}$ of $\mathrm{Pb}, \mathrm{Cd}$ and $\mathrm{Zn}$. The highest average CFs for $\mathrm{Cr}$ (0.6) and As (1.1) were all in the Southern Waters. The CF results showed that Xiamen Bay had low contamination levels and was moderately polluted by $\mathrm{Cu}, \mathrm{Pb}, \mathrm{Zn}, \mathrm{Cd}, \mathrm{Cr}$ and $\mathrm{As}$, and it had low pollution to very high contamination levels of $\mathrm{Hg}$. Hg had a maximum CF at site D25 in Tongan Bay, indicating that these sites were highly contaminated, and 27 of the 43 stations were considerably polluted by $\mathrm{Hg}$. 


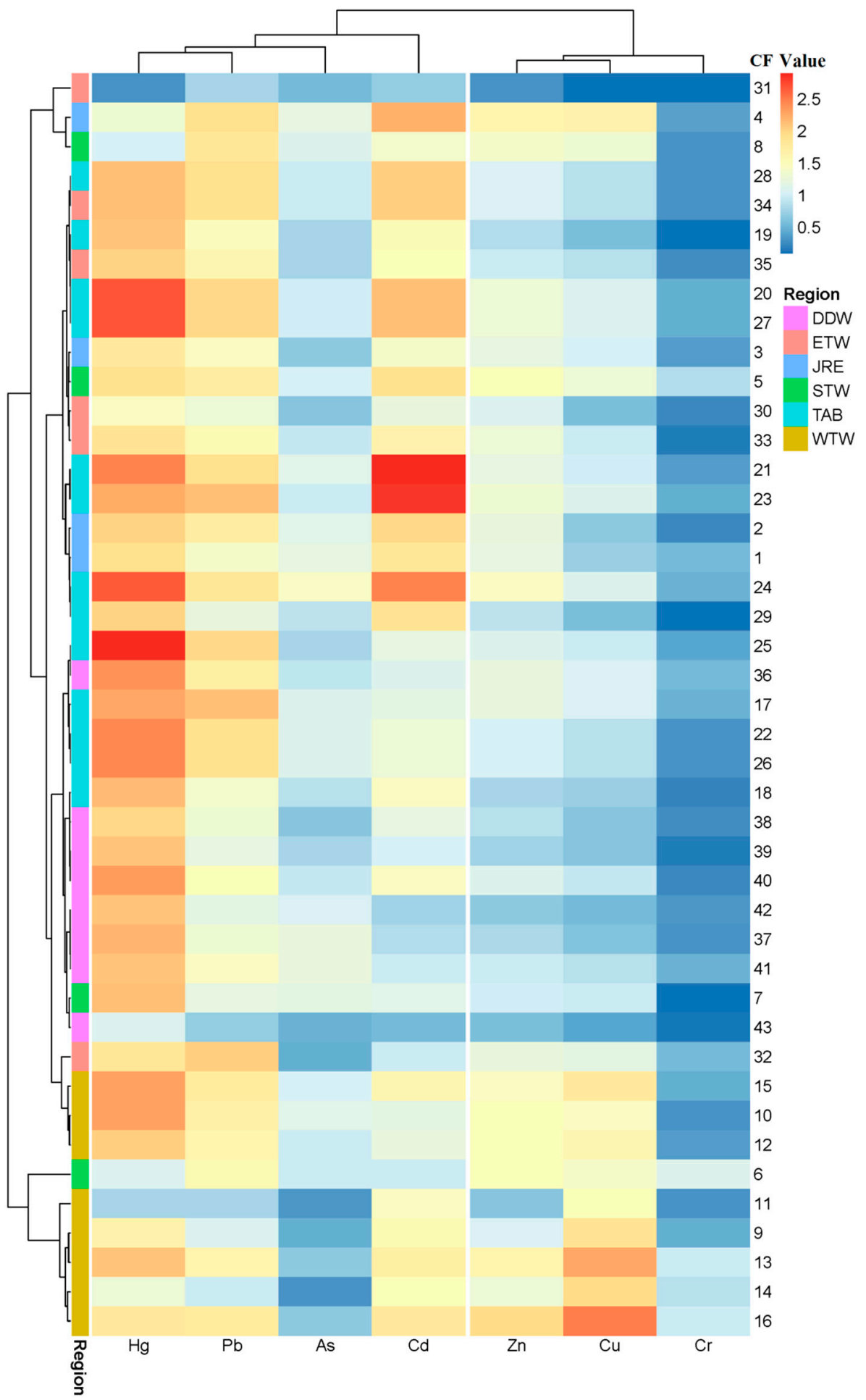

Figure 4. Cluster heatmap of the contamination factor (CF).

Table 2. The contamination factor (CF) and pollution load index (PLI) of the PTEs in the surface sediments of Xiamen Bay.

\begin{tabular}{cccccccccc}
\hline \multicolumn{2}{c}{ PTEs Pollution Index } & $\mathbf{C u}$ & $\mathbf{P b}$ & $\mathbf{Z n}$ & $\mathbf{C d}$ & $\mathbf{C r}$ & As & Hg & PLI \\
\hline \multirow{4}{*}{ CF } & Min. & 0.03 & 0.62 & 0.25 & 0.49 & 0.03 & 0.25 & 0.24 & 0.19 \\
& Max. & 4.64 & 3.41 & 2.89 & 6.45 & 1.17 & 1.70 & 6.40 & 1.96 \\
& Mean & 1.31 & 2.06 & 1.23 & 2.13 & 0.34 & 0.87 & 3.33 & 1.19 \\
\hline
\end{tabular}


The pollution load index (PLI) has been adopted by many researchers to explain the overall impact of PTEs pollution [40]. The PLI value $(>1)$ indicated that the surface sediment quality was polluted [55]. The PLI was between 0.2 and 2.0 in Xiamen Bay sediments (Figure 5). The average PLI values followed the order of the following regions: Western Waters $>$ Tongan Bay $>$ Jiulong River Estuary $>$ Southern Waters $>$ Dadeng Waters $>$ Eastern Waters. There were four areas with PLIs $>1$ in the five study areas, indicating that these four regions were contaminated by PTEs. According to the PLI classification, most of the sediment sites were contaminated (PLI $>1$ ). However, higher PLI values indicate that $\mathrm{Hg}$ and $\mathrm{Cd}$ were the leading causes of sediment pollution. The average PLI value indicated that the Xiamen Bay sediment was moderately polluted by PTEs.

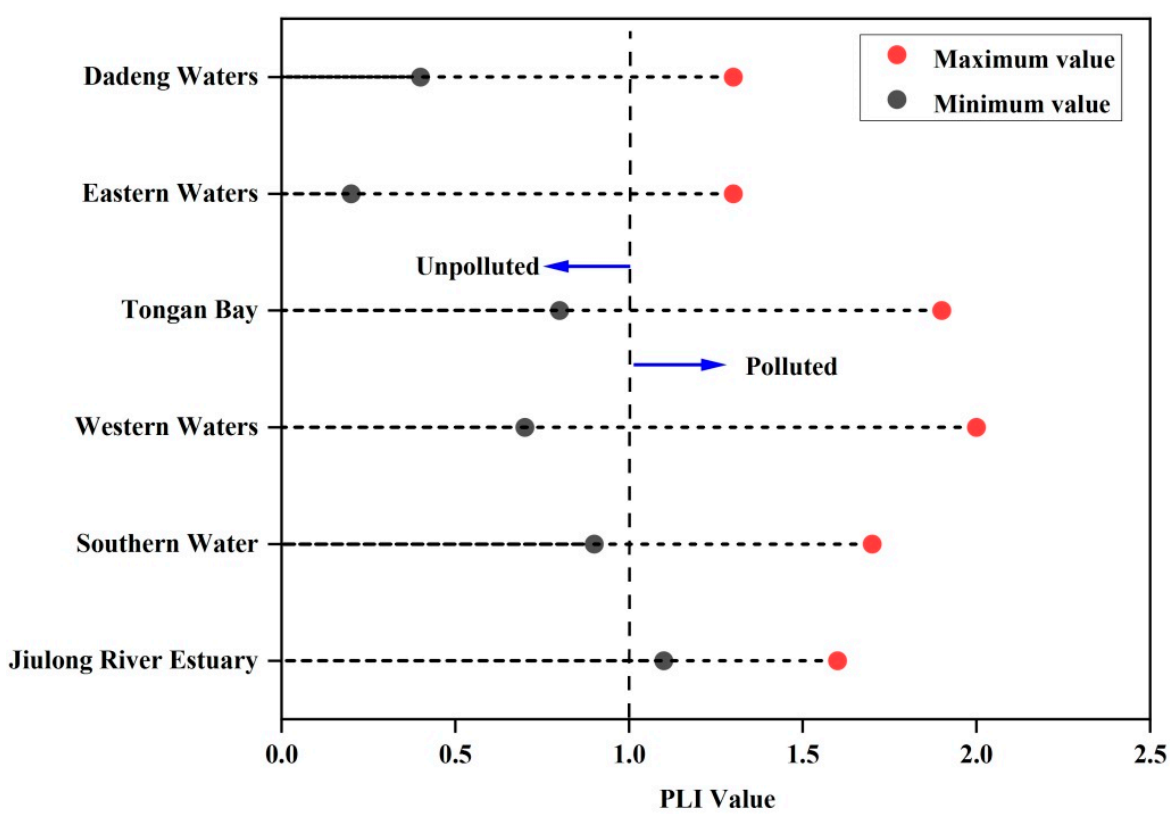

Figure 5. Lollipop chart of the pollution load index (PLI) in the subregions of Xiamen Bay.

\subsubsection{Igeo Results}

Igeo is a method to divide the PTE sediment contents into different pollution levels by multiplying its background value. According to Figure 6, the Igeo range of each PTE was $-5.81 \sim 1.63$ for $\mathrm{Cu},-1.29 \sim 1.18$ for $\mathrm{Pb},-2.58 \sim 0.95$ for $\mathrm{Zn},-1.61 \sim 2.10$ for $\mathrm{Cd},-5.91 \sim-0.36$ for $\mathrm{Cr},-2.60 \sim 0.18$ for As, and $-2.64 \sim 2.09$ for $\mathrm{Hg}$, with average values of $-0.62(\mathrm{Cu})$, $0.35(\mathrm{~Pb}),-0.36(\mathrm{Zn}), 0.23(\mathrm{Cd}),-2.48(\mathrm{Cr}), \mathrm{As}(-0.84)$ and $\mathrm{Hg}(0.88)$, respectively. The Igeo values indicated that $\mathrm{Cr}$ did not contaminate the Xiamen Bay sediment $(\mathrm{Igeo}<1)$ and the sediment was unpolluted to moderately polluted by $\mathrm{Zn}$ and As, moderately contaminated by $\mathrm{Cu}$ and $\mathrm{Pb}(\mathrm{Igeo}<2)$, and moderately to strongly contaminated by $\mathrm{Cd}$ and $\mathrm{Hg}$.

\subsubsection{Ecological Risk Assessment}

The Hakanson ecological risk index (RI) not only considers the concentration of different metal elements but also considers the biological toxicity response of different PTEs and is one of the most commonly used potential ecological hazard assessment methods [43]. The potential ecological hazards of seven PTEs in the sediments of Xiamen Bay are in order from strong to weak: $\mathrm{Hg}(125.7)>\mathrm{Cd}(62.1)>\mathrm{Cr}(13.7)>\mathrm{Pb}(10.3)>\mathrm{As}$ (9.1) $>\mathrm{Cu}$ (6.3) $>\mathrm{Zn}$ (1.3). The ecological risk indices of $\mathrm{Zn}, \mathrm{As}, \mathrm{Cu}$ and $\mathrm{Pb}$ were all less than 40 , which were at the level of slight ecological risk and had little impact on the potential ecological risk of surface sediments in Xiamen Bay. $\mathrm{Cr}$ at one sampling site reached the level of moderate ecological risk, and all other sample points were at the level of slight ecological risk, indicating that chromium made little contribution to the ecological risk of sediment in Xiamen Bay. The samples of Cd at slight ecological risk levels accounted for $32.56 \%$ of the total samples, the percentage of samples at medium ecological risk levels was 
$44.18 \%$, and the percentages of samples at strong ecological risk levels reached $18.61 \%$ and $4.65 \%$, respectively. A total of $32.45 \%$ of the $\mathrm{Hg}$ samples reached the medium ecological risk level, $64.9 \%$ of the samples reached the strong ecological risk level, and $1.53 \%$ and $0.18 \%$ of the samples reached the strong and extremely strong ecological risk levels, respectively. The potential ecological risks of PTEs in the surface sediment in Xiamen Bay were mainly caused by $\mathrm{Cd}$ and $\mathrm{Hg}$ (Figure 7). Previous studies found that $\mathrm{Hg}$ and $\mathrm{Cd}$ had higher hazard risks for sediments along coastal regions in China [6,48,56,57].

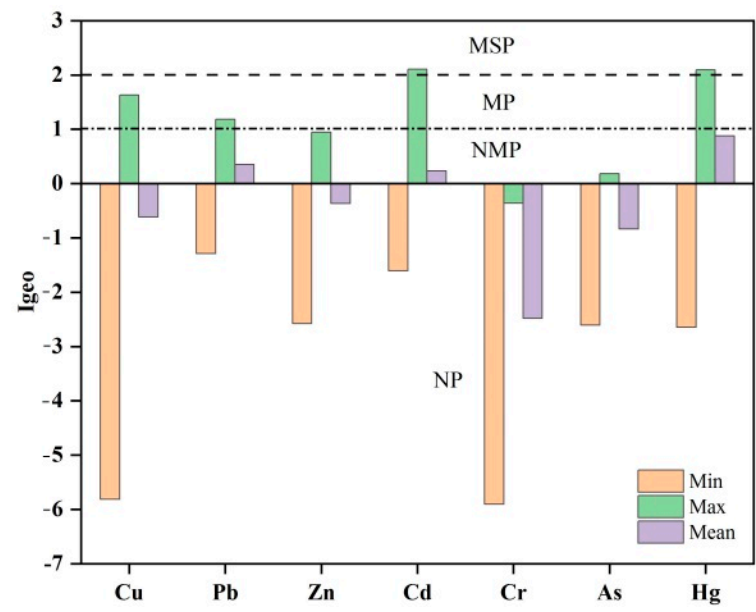

Figure 6. Histogram of the Igeo in the surface sediment of Xiamen Bay (NP = no pollution; NMP = no to moderate pollution; $\mathrm{MP}=$ moderate pollution; $\mathrm{MSP}=$ moderate to strong pollution).
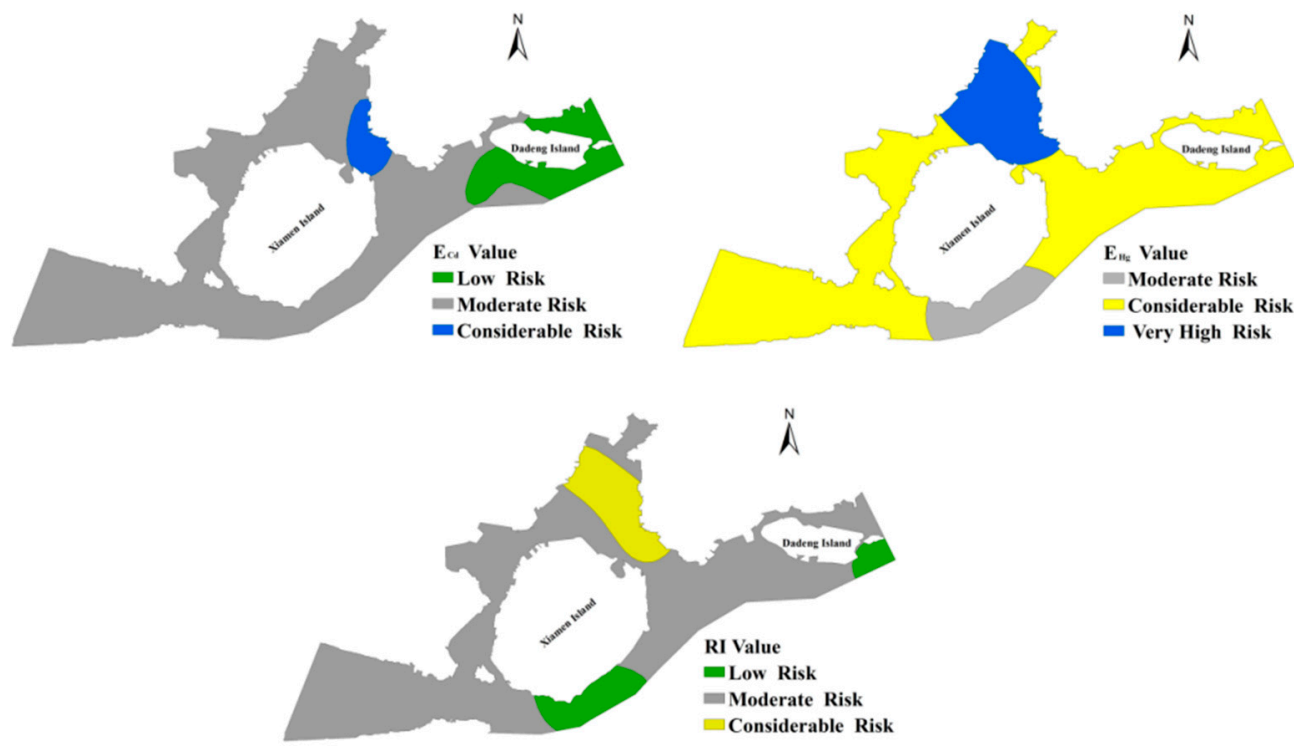

Figure 7. Spatial distribution map of the potential ecological risk of PTEs in Xiamen Bay.

The RI values of surface sediments in Xiamen Bay that were calculated based on the PTEs content of 43 sampling points were between 38.4 and 418.6, with an average value of 228.5, indicating that the surface sediments in Xiamen Bay had moderate potential ecological hazard according to the risk level. As shown in Figure 7, the proportions of samples with low, medium and strong risk levels were $11.63 \%, 74.42 \%$ and $13.95 \%$, respectively, and most of the samples were at a medium risk level. The average RI values of sediment in the studied regions were in the following order: Tongan Bay > Jiulong River Estuary $>$ Western Waters $>$ Dadeng Waters $>$ Southern Waters $>$ Eastern Waters. The highest RI value was observed at Tongan Bay. 


\subsection{Source Analysis of PTE Pollution in Sediments}

The Pearson correlation analysis of PTEs in sediments in Xiamen Bay is shown in Figure 8. Sulfide and TOC had significant correlations with lead and zinc but not with other PTEs, while the correlation coefficient between sulfide and organic carbon was high. Previous studies have reported that organic matter in sediments plays a key role in the content distribution, migration and transformation of PTEs, and there is a significant correlation between them [58,59], while other studies have found that there is no correlation between some metals and organic carbon in sediments, which may be due to the circulation and redistribution of metal elements caused by human input and natural depositional processes $[60,61]$. There were significant positive correlations between $\mathrm{Cu}, \mathrm{Zn}$ and $\mathrm{Cr}$ in the surface sediment, indicating that they may have similar or the same sources. Previous studies have shown that $\mathrm{Cr}$ is less affected by anthropogenic influence and is mainly controlled by the parent rock $[19,62]$. According to Figure 8., there were high positive correlations between lead and zinc, cadmium, mercury and arsenic, which suggests that these five metals originated from similar pollution sources and methods.

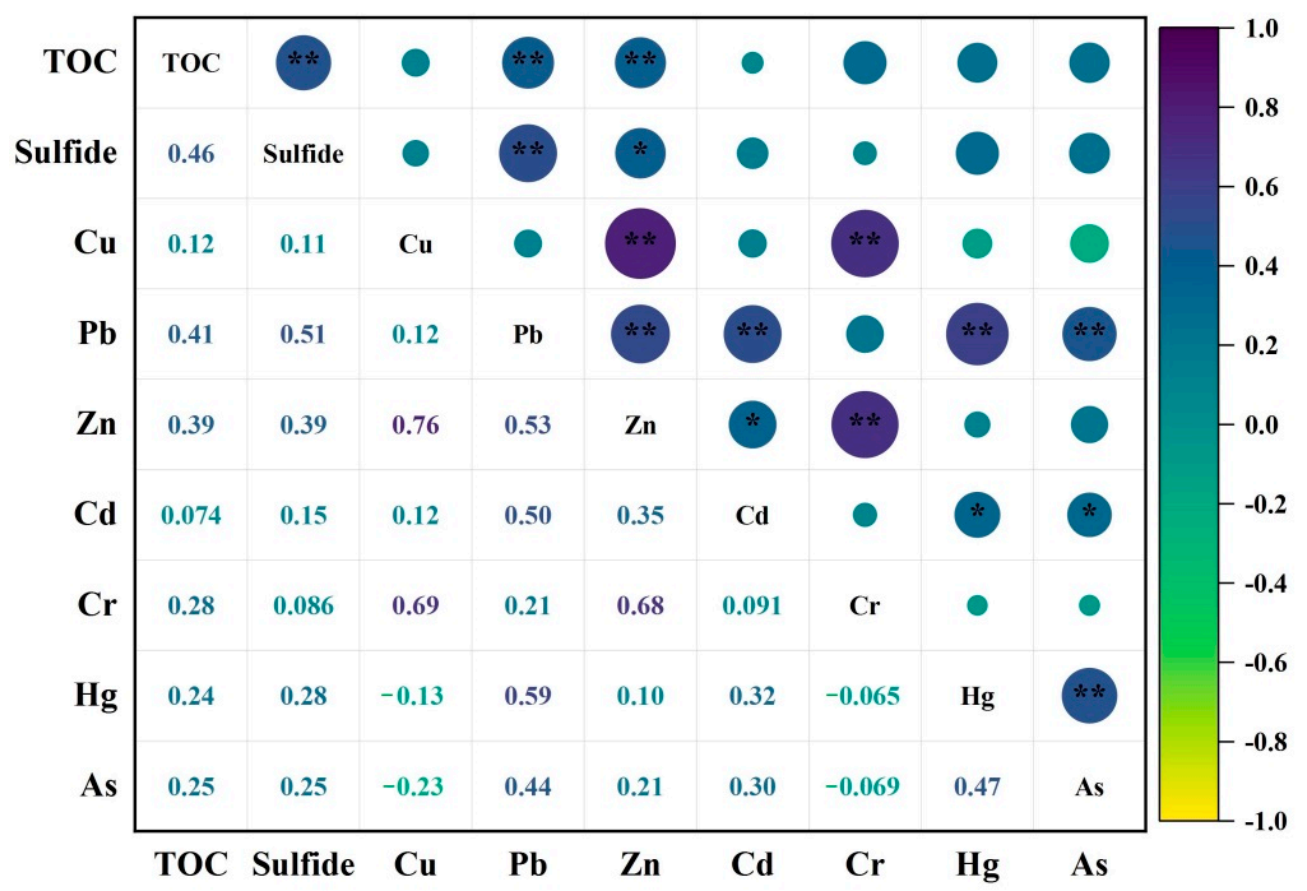

Figure 8. Correlation analysis of PTEs, TOC and sulfide in the surface sediment of Xiamen Bay $\left({ }^{*} p \leq 0.05,{ }^{* *} p \leq 0.01\right.$.).

In the present study, positive matrix factorisation (PMF) was used to further explore the sources of PTEs in the surface sediment of Xiamen Bay. The trend of the source composition spectrum and contribution rate of three factors of PMF source analysis is shown in Figure 9. Factor 1 had the highest contribution rate to $\mathrm{Cd}$ and As and the lowest contribution rate to the total amount and concentration of $\mathrm{Cr}$. Previous studies have shown that $\mathrm{As}$ and $\mathrm{Cd}$ are generally considered to be related to the use of chemical fertilisers and pesticides in human agricultural activities. Factor 1 was the input of chemical fertiliser and medication from human activities.

Factor 2 was characterised by high mercury and lead contents. Some previous studies have found that $\mathrm{Pb}$ in marine sediments mainly comes from natural sources, such as volcanic eruptions and forest fires, as well as atmospheric deposition produced by human activities [53,63]. Research has shown that mercury in sediments comes from the use of fossil fuels, such as coal-fired plants [36]. Therefore, factor 2 was mainly anthropogenic atmospheric input.

The elements with higher load ratios in factor 3 included $\mathrm{Cu}$ and $\mathrm{Cr}$, with contribution rates of $80.39 \%$ and $61.73 \%$, respectively. The average values of $\mathrm{Cr}$ and $\mathrm{Cu}$ in the sediments 
did not exceed the elemental background values, and the pollution evaluation grades were clean. Therefore, factor 3 was mainly the input of terrestrial detritus.
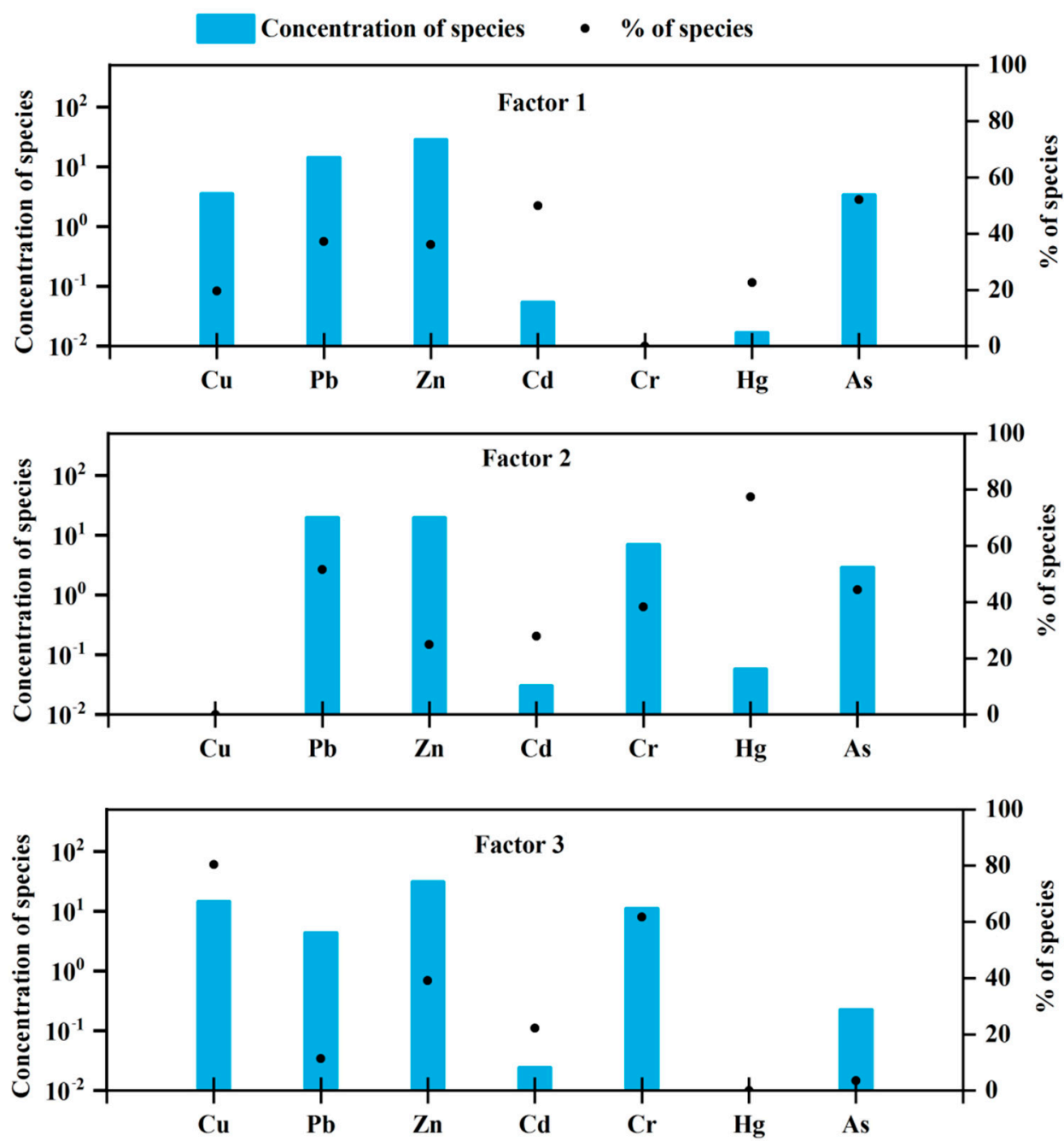

Figure 9. Source profile ratios in the sediments of Xiamen Bay for different PTEs.

\section{Conclusions}

In this study, the concentration and spatial distribution of PTEs in surface sediments in different areas of Xiamen Bay were comprehensively analysed. We evaluated the pollution degree and potential ecological risk of PTEs through the PLI, Igeo and RI and used the PMF model to explore their possible anthropogenic sources. The results of the study showed that there were significant differences in the contents and distribution of the seven selected PTEs in different sea areas of Xiamen Bay. Except for $\mathrm{Cr}$ and $\mathrm{Zn}$, the PTEs had different levels of ecological risks; $\mathrm{Cd}$ and $\mathrm{Hg}$ had higher ecological risks. The results of the PMF model showed that natural sources, anthropogenic atmospheric inputs, and chemical fertilizers and drugs were the main sources of PTE pollution in the surface sediments of Xiamen Bay. In particular, the $\mathrm{Hg}$ content was significantly affected by human activities, which should be given special attention.

Supplementary Materials: The following are available online at https:/ /www.mdpi.com/article / 10.3390/ijerph182312476/s1, Table S1: Each sampling station in Xiamen Bay.

Author Contributions: Writing-original draft preparation, data curation, investigation, W.W.; Writingreview and editing, R.J. and C.L.; Visualization, L.W.; Investigation, experimental analysis, Y.L., J.C. and H.L. All authors have read and agreed to the published version of the manuscript. 
Funding: This research was funded by The Fundamental Research Project of Third Institute of Oceanography of Ministry of Natural Resources, grant number 2013007.

Institutional Review Board Statement: Not applicable.

Informed Consent Statement: Not applicable.

Data Availability Statement: The data presented in this study are available on request from the corresponding author.

Conflicts of Interest: The authors declare no conflict of interest.

\section{References}

1. Yang, G.; Song, Z.; Sun, X.; Chen, C.; Ke, S.; Zhang, J. Heavy metals of sediment cores in Dachan Bay and their responses to human activities. Mar. Pollut. Bull. 2020, 150, 110764. [CrossRef] [PubMed]

2. Bastami, K.D.; Bagheri, H.; Haghparast, S.; Soltani, F.; Hamzehpoor, A.; Bastami, M.D. Geochemical and geo-statistical assessment of selected heavy metals in the surface sediments of the Gorgan Bay, Iran. Mar. Pollut. Bull. 2012, 64, 2877-2884. [CrossRef] [PubMed]

3. Li, M.; Zhu, S.; Ouyang, T.; Tang, J.; Tang, Z. Magnetic properties of the surface sediments in the Yellow River Estuary and Laizhou Bay, Bohai Sea, China: Implications for monitoring heavy metals. J. Hazard. Mater. 2019, 410, 124579. [CrossRef] [PubMed]

4. Armid, A.; Shinjo, R.; Zaeni, A.; Sani, A.; Ruslan, R. The distribution of heavy metals including Pb, Cd and Cr in Kendari Bay surficial sediments. Mar. Pollut. Bull. 2014, 84, 373-378. [CrossRef]

5. Gholizadeh, M.; Patimar, R. Ecological risk assessment of heavy metals in surface sediments from the Gorgan Bay, Caspian Sea. Mar. Pollut. Bull. 2018, 137, 662-667. [CrossRef]

6. Liu, B.; Xu, M.; Wang, J.; Wang, Z.; Zhao, L. Ecological risk assessment and heavy metal contamination in the surface sediments of Haizhou Bay, China. Mar. Pollut. Bull. 2021, 163, 111954. [CrossRef]

7. Rezaei, M.; Kafaei, R.; Mahmoodi, M.; Sanati, A.M.; Vakilabadi, D.R.; Arfaeinia, H.; Dobaradaran, S.; Sorial, G.A.; Ramavandi, B.; Boffito, D.C. Heavy metals concentration in mangrove tissues and associated sediments and seawater from the north coast of Persian Gulf, Iran: Ecological and health risk assessment. Environ. Nanotechnol. Monit. Manag. 2021, 15, 100456. [CrossRef]

8. Zhang, M.; Sun, X.; Xu, J. Heavy metal pollution in the East China Sea: A review. Mar. Pollut. Bull. 2020, 159, 111473. [CrossRef]

9. Dou, Y.; Li, J.; Zhao, J.; Hu, B.; Yang, S. Distribution, enrichment and source of heavy metals in surface sediments of the eastern Beibu Bay, South China Sea. Mar. Pollut. Bull. 2013, 67, 137-145. [CrossRef]

10. Zhang, M.; Chen, G.; Luo, Z.; Sun, X.; Xu, J. Spatial distribution, source identification, and risk assessment of heavy metals in seawater and sediments from Meishan Bay, Zhejiang coast. China. Mar. Pollut. Bull. 2020, 156, 111217. [CrossRef]

11. Luo, H.; Wang, Q.; Liu, Z.; Wang, S.; Long, A.; Yang, Y. Potential bioremediation effects of seaweed Gracilaria lemaneiformis on heavy metals in coa sediment from a typical mariculture zone. Chemosphere 2020, 245, 125636. [CrossRef]

12. Arikibe, J.E.; Prasad, S. Determination and comparison of selected heavy metal concentrations in seawater and sediment samples in the coastal area of Suva, Fiji. Mar. Pollut. Bull. 2020, 157, 111157. [CrossRef]

13. Kumar, S.B.; Padhi, R.K.; Mohanty, A.K.; Satpathy, K.K. Distribution and ecological- and health-risk assessment of heavy metals in the seawater of the southeast coast of India. Mar. Pollut. Bull. 2020,161, 111712. [CrossRef]

14. Wang, X.-N.; Gu, Y.-G.; Wang, Z.-H.; Ke, C.-L.; Mo, M.-S. Biological risk assessment of heavy metals in sediments and health risk assessment in bivalve mollusks from Kaozhouyang Bay, South China. Mar. Pollut. Bull. 2018, 133, 312-319. [CrossRef]

15. Ahmad, K.; Muhammad, S.; Ali, W.; Jadoon, I.A.K.; Rasool, A. Occurrence, source identification and potential risk evaluation of heavy metals in sediments of the Hunza River and its tributaries, Gilgit-Baltistan. Environ. Technol. Innov. 2020, 18, 100700. [CrossRef]

16. Caballero-Gallardo, K.; Alcala-Orozco, M.; Barraza-Quiroz, D.; De la Rosa, J.; Olivero-Verbel, J. Environmental risks associated with trace elements in sediments from Cartagena Bay, an industrialized site at the Caribbean. Chemosphere 2020, $242,125173$. [CrossRef]

17. Han, D.; Cheng, J.; Hu, X.; Jiang, Z.; Mo, L.; Xu, H.; Ma, Y.; Chen, X.; Wang, H. Spatial distribution, risk assessment and source identification of heavy metals in sediments of the Yangtze River Estuary, China. Mar. Pollut. Bull. 2017, 115, 141-148. [CrossRef]

18. Maurya, P.; Kumari, R. Toxic metals distribution, seasonal variations and environmental risk assessment in surficial sediment and mangrove plants (A. marina), Gulf of Kachchh (India). J. Hazard. Mater. 2021, 413, 125345. [CrossRef]

19. Zhuang, W.; Zhou, F. Distribution, source and pollution assessment of heavy metals in the surface sediments of the Yangtze River Estuary and its adjacent East China Sea. Mar. Pollut. Bull. 2021, 164, 112002. [CrossRef]

20. Zhang, D.; Lu, D.; Yang, B.; Zhang, J.; Ning, Z.; Yu, K. Influence of natural and anthropogenic factors on spatial-temporal hydrochemistry and the susceptibility to nutrient enrichment in a subtropical estuary. Mar. Pollut. Bull. 2019, 146, 945-954. [CrossRef]

21. Lin, H.; Lan, W.; Feng, Q.; Zhu, X.; Li, T.; Zhang, R.; Song, H.; Zhu, Y.; Zhao, B. Pollution and ecological risk assessment, and source identification of heavy metals in sediment from the Beibu Gulf, South China Sea. Mar. Pollut. Bull. 2021, 168, 112403. [CrossRef] [PubMed] 
22. Elsagh, A.; Jalilian, H.; Aslshabestari, M.G. Evaluation of heavy metal pollution in coastal sediments of Bandar Abbas, the Persian Gulf, Iran: Mercury pollution and environmental geochemical indices. Mar. Pollut. Bull. 2021, 167, 112314. [CrossRef] [PubMed]

23. Fang, J.; Chen, J.; Li, Y.; Ke, S. Study of modern sedimentary environment in the Xiamen Bay. Acta Sedimentol. Sin. 2010, 28, 356-364.

24. Ma, L.; Lin, B.-L.; Chen, C.; Horiguchi, F.; Eriguchi, T.; Li, Y.; Wang, X. A 3D-hydrodynamic model for predicting the environmental fate of chemical pollutants in Xiamen Bay, southeast China. Environ. Pollut. 2020, 256, 113000. [CrossRef] [PubMed]

25. Zhang, L.; Feng, H.; Li, X.; Ye, X.; Jing, Y.; Ouyang, T.; Yu, X.; Liang, R.; Chen, W. Heavy metal contaminant remediation study of western Xiamen Bay sediment, China: Laboratory bench scale testing results. J. Hazard. Mater. 2009, 172, 108-116. [CrossRef]

26. Zhang, L.; Ye, X.; Feng, H.; Jing, Y.; Ouyang, T.; Yu, X.; Liang, R.; Gao, C.; Chen, W. Heavy metal contamination in western Xiamen Bay sediments and its vicinity, China. Mar. Pollut. Bull. 2007, 54, 974-982. [CrossRef]

27. Hu, G.; Lin, C.; Yang, Q.; Yan, Y.; Huang, H.; Yu, R.; Cui, J.; Yan, Y. Distribution and source appointment of rare earth elements in offshore sediments of Western Xiamen Bay, Southeast China. J. Geochem. Explor. 2019, 201, 31-39. [CrossRef]

28. Lin, P.; Guo, L.; Chen, M.; Cai, Y. Distribution, partitioning and mixing behavior of phosphorus species in the Jiulong River estuary. Mar. Chem. 2013, 157, 93-105. [CrossRef]

29. Yu, W.; Zhang, L.; Ricci, P.F.; Chen, B.; Huang, H. Coastal ecological risk assessment in regional scale: Application of the relative risk model to Xiamen Bay, China. Ocean Coast. Manag. 2015, 108, 131-139. [CrossRef]

30. Huang, W.; Corbett, J.J.; Jin, D. Regional economic and environmental analysis as a decision support for marine spatial planning in Xiamen. Mar. Policy 2015, 51, 555-562. [CrossRef]

31. Dalia, M.S.; Aly Salem, A.K.A.E. Comprehens ive risk assessment of heavy metals in surface sediments along the Egyptian Red Sea coast. Egypt. J. Aquat. Res. 2014, 40,349-362.

32. Wang, S.; Liu, J.; Li, J.; Xu, G.; Qiu, J.; Chen, B. Environmental magnetic parameter characteristics as indicators of heavy metal pollution in the surface sediments off the Zhoushan Islands in the East China Sea. Mar. Pollut. Bull. 2020, 150, 110642. [CrossRef]

33. Usman, Q.A.; Muhammad, S.; Ali, W.; Yousaf, S.; Jadoon, I.A. Spatial distribution and provenance of heavy metal contamination in the sediments of the Indus River and its tributaries, North Pakistan: Evaluation of pollution and potential risks. Environ. Technol. Innov. 2021, 21, 101184. [CrossRef]

34. Bastami, K.D.; Bagheri, H.; Kheirabadi, V.; Zaferani, G.G.; Teymori, M.B.; Hamzehpoor, A.; Soltani, F.; Haghparast, S.; Harami, S.R.M.; Ghorghani, N.F.; et al. Distribution and ecological risk assessment of heavy metals in surface sediments along southeast coast of the Caspian Sea. Mar. Pollut. Bull. 2014, 81, 262-267. [CrossRef]

35. James, P.B.; Godwin, A.A.; Wayde, N.M.; Ashantha, G. Enrichment, distribution and sources of heavy metals in the sediments of Deception Bay, Queensland, Australia. Mar. Pollut. Bull. 2014, 81, 248-255.

36. Liu, P.; Hu, W.; Tian, K.; Huang, B.; Zhao, Y.; Wang, X.; Zhou, Y.; Shi, B.; Kwon, B.; Choi, K.; et al. Accumulation and ecological risk of heavy metals in soils along the coastal areas of the Bohai Sea and the Yellow Sea: A comparative study of China and South Korea. Environ. Int. 2020, 137, 105519. [CrossRef]

37. Muller, G. Index of Geoaccumulation in Sediments of the Rhine River. Geo. J. 1969, 2, 109-118.

38. Xu, F.; Liu, Z.; Yingchang, C.; Qiu, L.; Feng, J.; Xu, F.; Tian, X. Assessment of heavy metal contamination in urban river sediments in the Jiaozhou Bay catchment, Qingdao, China. Catena 2017, 150, 9-16. [CrossRef]

39. Joy, A.; P P, A.; R, R.; Mathew, J.; Mathew, A.; Gopinath, A. Spatial variation of trace element concentration and contamination assessment in the coral reef sediments of Lakshadweep Archipelago, Indian Ocean. Mar. Pollut. Bull. 2019, 146, 106-116. [CrossRef]

40. Hoang, H.-G.; Lin, C.; Tran, H.-T.; Chiang, C.-F.; Bui, X.-T.; Cheruiyot, N.K.; Shern, C.-C.; Lee, C.-W. Heavy metal contamination trends in surface water and sediments of a river in a highly-industrialized region. Environ. Technol. Innov. 2020, $20,101043$. [CrossRef]

41. Rajeshkumar, S.; Liu, Y.; Zhang, X.; Ravikumar, B.; Bai, G.; Li, X. Studies on seasonal pollution of heavy metals in water, sediment, fish and oyster from the Meiliang Bay of Taihu Lake in China. Chemosphere 2018, 191, 626-638. [CrossRef] [PubMed]

42. Pratap, A.; Mani, F.S.; Prasad, S. Heavy metals contamination and risk assessment in sediments of Laucala Bay, Suva, Fiji. Mar. Pollut. Bull. 2020, 156, 111238. [CrossRef] [PubMed]

43. Håkanson, L. An ecological risk index for aquatic pollution control: A sedimentological approach. Pergamon 1980, 14, 975-1001. [CrossRef]

44. Liu, X.; Zhang, L. Concentration, risk assessment, and source identification of heavy metals in surface sediments in Yinghai: A shellfish cultivation zone in Jiaozhou Bay, China. Mar. Pollut. Bull. 2017, 121, 216-221. [CrossRef]

45. Liang, X.; Song, J.; Duan, L.; Yuan, H.; Li, X.; Li, N.; Qu, B.; Wang, Q.; Xing, J. Source identification and risk assessment based on fractionation of heavy metals in surface sediments of Jiaozhou Bay, China. Mar. Pollut. Bull. 2018, 128, 548-556. [CrossRef]

46. Liu, Q.; Jia, Z.; Li, S.; Hu, J. Assessment of heavy metal pollution, distribution and quantitative source apportionment in surface sediments along a partially mixed estuary (Modaomen, China). Chemosphere 2019, 225, 829-838. [CrossRef]

47. Vu, C.T.; Lin, C.; Shern, C.-C.; Yeh, G.; Le, V.G.; Tran, H.T. Contamination, ecological risk and source apportionment of heavy metals in sediments and water of a contaminated river in Taiwan. Ecol. Indic. 2017, 82, 32-42. [CrossRef]

48. Ding, X.; Ye, S.; Laws, E.A.; Mozdzer, T.J.; Yuan, H.; Zhao, G.; Yang, S.; He, L.; Wang, J. The concentration distribution and pollution assessment of heavy metals in surface sediments of the Bohai Bay, China. Mar. Pollut. Bull. 2019, 149, 110497. [CrossRef] 
49. Mao, L.; Ye, H.; Li, F.; Tao, H.; Shi, L.; Chen, L.; Shi, W.; Yan, G.; Chen, H. Source-oriented variation in trace metal distribution and fractionation in sediments from developing aquaculture area-A case study in south Hangzhou bay, China. Mar. Pollut. Bull. 2017, 125, 389-398. [CrossRef]

50. Zhao, G.; Ye, S.; Yuan, H.; Ding, X.; Wang, J. Distribution and contamination of heavy metals in surface sediments of the Daya Bay and adjacent shelf, China. Mar. Pollut. Bull. 2016, 112, 420-426. [CrossRef]

51. Christophoridis, C.; Bourliva, A.; Evgenakis, E.; Papadopoulou, L.; Fytianos, K. Effects of anthropogenic activities on the levels of heavy metals in marine surface sediments of the Thessaloniki Bay, Northern Greece: Spatial distribution, sources and contamination assessment. Microchem. J. 2019, 149, 104001. [CrossRef]

52. State Oceanic Administration. Marine Sediment Quality; The People's Republic of China National Standards: Beijing, China, 2002. (In Chinese)

53. Zhai, B.; Zhang, X.; Wang, L.; Zhang, Z.; Zou, L.; Sun, Z.; Jiang, Y. Concentration distribution and assessment of heavy metals in surface sediments in the Zhoushan Islands coastal sea, East China Sea. Mar. Pollut. Bull. 2021, 164, 112096. [CrossRef]

54. Pinedo, S.; Jordana, E.; Flagella, M.M.; Ballesteros, E. Relationships Between Heavy Metals Contamination in Shallow Marine Sediments with Industrial and Urban Development in Catalonia (Northwestern Mediterranean Sea). Water Air Soil Pollut. 2014, 225, 1-16. [CrossRef]

55. Qutu, J.; Junyu, H.; Guanqiong, Y.; George, C. Heavy metal contamination assessment of surface sediments of the East Zhejiang coastal area during 2012-2015. Ecotox. Environ. Safe. 2018, 163, 444-455. [CrossRef]

56. Li, F.; Mao, L.; Jia, Y.; Gu, Z.; Shi, W.; Chen, L.; Ye, H. Distribution and risk assessment of trace metals in sediments from Yangtze River estuary and Hangzhou Bay, China. Environ. Sci. Pollut. Res. 2018, 25, 855-866. [CrossRef]

57. Zhang, A.; Wang, L.; Zhao, S.; Yang, X.; Zhao, Q.; Zhang, X.; Yuan, X. Heavy metals in seawater and sediments from the northern Liaodong Bay of China: Levels, distribution and potential risks. Reg. Stud. Mar. Sci. 2017, 11, 32-42. [CrossRef]

58. Xu, F.; Hu, B.; Yuan, S.; Zhao, Y.; Dou, Y.; Jiang, Z.; Yin, X. Heavy metals in surface sediments of the continental shelf of the South Yellow Sea and East China Sea: Sources, distribution and contamination. Catena 2018, 160, 194-200. [CrossRef]

59. Kucuksezgin, F.; Kontas, A.; Uluturhan, E. Evaluations of heavy metal pollution in sediment and Mullus barbatus from the Izmir Bay (Eastern Aegean) during 1997-2009. Mar. Pollut. Bull. 2011, 62, 1562-1571. [CrossRef]

60. El Bilali, L.; Rasmussen, P.E.; Hall, G.E.M.; Fortin, D. Role of sediment composition in trace metal distribution in lake sediments. Appl. Geochem. 2002, 17, 1171-1181. [CrossRef]

61. Ghrefat, H.; Yusuf, N. Assessing Mn, Fe, Cu, Zn, and Cd pollution in bottom sediments of Wadi Al-Arab Dam, Jordan. Chemosphere 2006, 65, 2114-2121. [CrossRef]

62. Cornu, S.; Lucas, Y.; Lebon, E.; Ambrosi, J.P.; Luizão, F.; Rouiller, J.; Bonnay, M.; Neal, C. Evidence of titanium mobility in soil profiles, Manaus, central Amazonia. Geoderma 1999, 91, 281-295. [CrossRef]

63. Cao, L.; Hong, G.H.; Liu, S. Metal elements in the bottom sediments of the Changjiang Estuary and its adjacent continental shelf of the East China Sea. Mar. Pollut. Bull. 2015, 95, 458-468. [CrossRef] 